\title{
Estudantes indígenas em uma escola não indígena: possibilidades para vivências interculturais
}

Maria Aparecida Bergamaschi*

Kátia Simone Müller Dickel ${ }^{*}$

\section{Resumo}

Este artigo decorre da pesquisa em uma escola indígena e em uma escola não indígena, realizada basicamente na perspectiva metodológica etnográfica, durante os anos de 2011 e 2012. Na escola não indígena foi observada a convivência com estudantes Kaingang que concluem o ensino fundamental, iniciado na escola da aldeia. A partir disso, foram descritas situações que mostram a educação e a escola no cotidiano Kaingang, bem como o cotidiano da escola não indígena, como ocorre a convivência e as possibilidades para a interculturalidade, as conflitualidades e as relaçôes de reciprocidade. $\mathrm{O}$ olhar dedicado para conhecer e descrever essa relação abre um campo de possibilidades decorrentes de trocas - às vezes desconfianças e isolamentos -, que oferecem contribuiçóes importantes, tanto para a educação e a escola indígena quanto para a educação e a escola não indígena.

Palavras-chave: Interculturalidade. Educação indígena. Escola kaingang.

*Doutora em Educaçáo pela Universidade Federal do Rio Grande do Sul (UFRGS). Professora da Faculdade de Educação e do Programa de Pós-Graduação na Universidade Federal do Rio Grande do Sul (UFRGS).

**Mestre em Educação pela Universidade Federal do Rio Grande do Sul (UFRGS). 


\section{Algumas palavras para contextualizar}

Este artigo é fruto da pesquisa realizada com um grupo de estudantes Kaingang que frequentam uma escola não indígena, próxima a sua aldeia, no município de São Leopoldo, no estado do Rio Grande do Sul.

$\mathrm{O}$ objetivo central que conduziu a investigação foi compreender a relação de convivência entre estudantes e professores, bem como entre as duas comunidades escolares - da escola indígena e da escola náo indígena -, também envolvidas nesse conviver. O olhar que dedicamos para conhecer e descrever essa relação abre um campo de possibilidades decorrentes de trocas - às vezes desconfianças e isolamentos -, que oferecem contribuiçóes importantes, tanto para a educação e a escola indígena quanto para a educação e a escola não indígena. Nesse sentido, a compreensão do modo de vida dos Kaingang se fez necessária nas relaçóes de convivência dos alunos dessa comunidade indígena que estudam numa escola fora de sua aldeia, levando em consideração as diferenças que os constituem e o desconhecimento que ainda predomina acerca dos povos indígenas. Do mesmo modo, conhecer o funcionamento da escola não indígena, os modos de vida e a atuação de seus atores na relação com os estudantes Kaingang, mostram caminhos para a compreensão de processos de interculturalidade.

A Escola Estadual Indígena de Ensino Fundamental Voga (Escola Voga) e a Escola Estadual de Ensino Médio Professora Haydée Mello Rostirolla (Escola Haydée) constituem o palco principal da pesquisa, onde foram observadas e registradas diferentes cenas, escutadas e consideradas diferentes vozes. Ambas as escolas situam-se no município de São Leopoldo, RS: uma na Terra Indígena Por Fi e a outra num bairro próximo à aldeia, porém mais afastado do centro da cidade. Obtivemos a autorização para a utilização do nome das duas escolas

Metodologicamente, a pesquisa teve na etnografia sua principal sustentação e propiciou e elaboração de um diário de campo, mas também se valeu de outros procedimentos metodológicos, como entrevistas dialogadas, entrevistas coletivas e registros de depoimentos. A escolha desse caminho nos possibilitou descrever o cotidiano dos estudantes Kaingang, aproveitando a sinergia dos diversos elementos que compóe a sua complexa vida social. Segundo Michel Maffesoli, (2001, p. 18), o cotidiano pode ser entendido como "um laboratório alquímico das minúsculas criaçôes que pontuam a vida cotidiana, como lugar de 'recriação' de 'si' e da manutenção da identidade que permite a 
resistência”. Essa metodologia também nos propiciou a compreensão de dois modelos de escola, permitindo repensar a pluralidade e a singularidade dos sujeitos envolvidos.

Salientamos que o presente estudo não teve pretensão de comparar os modelos das duas comunidades observadas, e sim descrever como cada uma é, a fim de apreender a convivência entre os atores que dão vida ao espetáculo que ocorre, diariamente, nessas escolas.

\section{Escola e educação kaingang}

No processo de escolarização entre os povos indígenas no país, destacamse relevantes incompreensóes na relação de contato, iniciadas ainda no período colonial e estendendo-se à criação do Serviço de Proteção ao Índio e Localização de Trabalhadores Nacionais (SPILTN), em 1910, mais tarde substituído pela Fundação Nacional do Índio (FUNAI). Salientamos a criação do SPITN como um marco importante na relação com os povos indígenas, pois, a partir de então, o Estado passa a acompanhar mais intensa e institucionalmente esses povos. Nas açóes do órgão indigenista, destaca-se a criação de escolas com o intuito de integrar os "índios selvagens" à comunháo nacional (LIMA, 1995).

Embora muitas incompreensóes permaneçam no que tange às relações institucionais com os povos indígenas, pois compreendemos que as interaçóes interculturais se constituem com as diferenças, a partir da dos anos 80 do século $\mathrm{XX}$, a escola indígena vem adquirindo importantes direitos, principalmente, no que diz respeito à legislação. Observamos, em um tempo mais recente, a atuação protagonista de lideranças, professores e estudantes indígenas conduzindo seus processos de escolarização, fazendo com que esta instituição nas Terras Indígenas adquira características próprias, caminhando intensamente para a concretização de uma escola específica, diferenciada e intercultural.

Certamente, isso se fez, e se faz, com a mobilização de lideranças indígenas de todo o país, reivindicando e construindo modelos escolares próprios, priorizando suas línguas, tradiçôes e memórias coletivas. Apesar da predominância de um modelo escolar imposto durante séculos de colonização, nossos estudos nos permitem afirmar que apostam numa escola aliada de suas lutas, que funcione também como um instrumento, uma ferramenta, como frequentemente dizem, para construírem relações respeitosas com as sociedades não indígenas. Os Kaingang da Aldeia Por Fi mobilizam-se para conseguir esse 
respeito, por isso querem ampliar sua escola e, assim, acolher os estudantes em todos os anos do ensino fundamental de forma específica e diferenciada.

Conversando com o professor da Escola Voga, ele nos disse que discutem questôes importantes para que a política pública de educação escolar leve em consideração a elaboração de seus planos de estudo, pensados a partir dos seus modos de vida. Embora a escola da aldeia siga uma organização coletiva Kaingang, apoiada em um documento elaborado no âmbito da Secretaria de Estado da Educação do Rio Grande do Sul como Projeto Político Pedagógico (PPP), ela busca uma proposta específica para a sua realidade:

Nós temos o nosso Projeto Politico Pedagógico. Para todas as escolas indigenas [Kaingang] do Rio Grande do Sul tem uma única proposta. Nós, aqui, nos baseamos naquela e fizemos o nosso plano. Mas a proposta, aqui, é fazer um "PPP" só para a escola daqui, porque cada comunidade tem uma organização diferente (Professor da Escola Voga, entrevista dialogada, 12 set. 2012).

Podemos dizer que as escolas indígenas estão em movimento na busca de direitos, envolvendo suas comunidades para pensar propostas pedagógicas diferenciadas, estudando e também valorizando trocas e aprendizagens com instituiçóes não indígenas. É o caso da Escola Indígena da Aldeia Por Fi, que participa de projetos de extensão proporcionados por professores e estudantes de universidades próximas. Além disso, um dos professores recém concluiu o curso de Pedagogia na Universidade Federal do Rio Grande do Sul (UFRGS), por meio de uma política educacional de ingresso e permanência de indígenas no ensino superior, que também é decorrência de mobilizaçóes para qualificar a educação escolar indígena. Nesse contexto, entre trocas de saberes e convivências com outras instituiçóes escolares e universitárias, a Escola Voga abre espaço para a interculturalidade, inaugurando caminhos para a reciprocidade no plano educacional.

Uma das imagens que elegemos para dizer como se faz a educação na Escola é que a sala de aula se parece com um cesto, trançado com fios coloridos de taquara, que está sendo construído a cada dia. Os estudantes e o professor são a matéria prima principal e vão se movimentando conforme suas vontades e necessidades, como as fibras de taquara desfiadas em tiras. Cada movimento é um trançado que vai sendo constituído. Quando vários 
estudantes se movimentam, formando um só grupo, percebemos os coloridos desse cesto a partir das aprendizagens que vão surgindo nesta relação. $\mathrm{O}$ riso, os olhos curiosos e atentos das pessoas Kaingang que circulam dentro e fora da escola contribuem para a fluidez desse movimento e para a formação do conhecimento, que está correlacionado aos seus valores culturais. Percebemos que o artesanato é uma presença forte entre os Kaingang, especialmente na aldeia Por Fi, situada próxima a grandes cidades, o que facilita a comercialização, possibilitando a compra de outras mercadorias que os sustentem, além de ser fonte direta de muitos alimentos. Os indígenas se utilizam da venda de artesanato como uma estratégia fundamental que mostra a sua força para preservar vínculos simbólicos, territoriais, econômicos e ecológicos com os campos e florestas (FREITAS, 2008). Nesse sentido, são comuns as cenas de mulheres desfiando, colorindo e trançando fibras de taquara, produzindo em seus trançados desenhos transmitidos de geração em geraçáo, mostrando que os grafismos Kaingang continuam vivos.

O povo Kaingang compóe o grupo de sociedades indígenas Jê Meridional e organiza sua vida social conforme um sistema conhecido como metades clânicas, nomeadas kame e kanhru kre. A primeira metade é representada pela marca comprida (desenho aberto). A segunda é representada pela marca redonda (desenho fechado). Essas "oposiçôes aberto/fechado, comprido/redondo são representações mentais dualistas contidas nos grafismos Kaingang, que se limitam a identificar as duas metades percebidas como cosmológicas, opostas e complementares" (SILVA, 2008, p. 21). A oposição e a complementaridade são explicadas pela e na mitologia Kaingang: kame e kanhru kre eram irmáos - sol e lua, respectivamente e, segundo narram, esses irmãos deram origem ao povo Kaingang. O dualismo presente nas metades está classificado juntamente com os seres da natureza, "incluindo os seres humanos" que possuem "valores associados às metades exogâmicas, como: forte ou fraco, alto ou baixo, valente ou medroso" (CLAUDINO, 2011, p. 45). Além de se materializarem nos grafismos, essas compreensóes cosmológicas, que constituem modos de vida, fazem parte da educação Kaingang, mas não são, necessariamente, conteúdos escolares.

Em nossas observaçóes, evidenciamos que a escola indígena não tem a função de ensinar como as crianças devem se (com)portar, comer ou vestir, mas, sim, passar conhecimentos que lhes deem sustentação para continuarem seus estudos fora da aldeia e ou compreender melhor o mundo não indígena. 
Nesse sentido, observamos que a língua e a história Kaingang fazem parte dos conteúdos da Escola Voga, embora a predominância do ensino esteja voltada para a decifração dos códigos não indígenas, fundamental para o preparo desses estudantes que circulam entre "os dois mundos". Também buscam a continuidade das aprendizagens escolares, pois seguir os estudos significa ampliar seus conhecimentos para atuarem e se relacionarem com os diversos setores da sociedade não indígena. Deixam transparecer, em suas práticas escolares, que o valor do estudo está relacionado aos saberes e não ao status, porém observamos que quando os estudantes Kaingang chegam à escola não indígena se deparam com algumas imposiçóes, ocorrendo, muitas vezes, o abandono escolar.

A educação que é praticada na escola indígena parece estar sendo experimentada. Ela "não está pronta, acabada, e sim em constante movimento", conforme as palavras do professor Kaingang. É dentro dessa perspectiva que o compartilhamento do espaço escolar é essencial, porque sua função se direciona a uma educação que está se fazendo, observando preceitos teórico-metodológicos Kaingang, em que a aprendizagem prescinde de "todos os seres vivos do planeta" (CARDOSO, 2014). Portanto, a metodologia Kaingang requer a presença das pessoas e dos animais, mesmo que predomine um conteúdo apoiado nos saberes da escola ocidental. Parece-nos que a educação para os indígenas não está separada dos pássaros, da água, da mata, enfim, ela é esse todo que refere o professor.

Durante as conversas que surgiam no nosso estar-junto ${ }^{1}$ e os depoimentos durante entrevistas com o professor, ficou explícito que o trabalho da Escola Voga faz um esforço para se assentar na filosofia do povo Kaingang. Segundo ele, a escola era uma instituição estranha, que parecia ter sido criada "mais para prejudicar do que para auxiliar os povos indígenas". Porém, com o passar do tempo, eles entenderam a política da instituição escolar e, atualmente, a consideram útil, pois usam a sua própria organizaçáo, inserindo a cultura estranha na sala de aula, a partir da oralidade, e, mantendo as portas abertas para que todas as pessoas da comunidade possam contribuir com suas experiências, criando nessa escola uma estética diferenciada.

O fato de experimentar em comum suscita um valor, é vetor de criação. Que esta seja macroscópica ou minúscula, que ela se ligue aos modos de vida, à produção, ao ambiente, à própria comunicação, não faz diferença. A potência coletiva cria uma obra de arte: a 
vida social em seu todo, e em suas diversas modalidades. É, portanto, a partir de uma arte generalizada que se pode compreender a estética como faculdade de sentir em comum. (MAFFESOLI, 1999, p. 28).

O compartilhamento da escola, o experimentar e sentir em comum, bem como o modo como os estudantes se organizam nesse espaço nos fez pensar nessas singularidades. Toda a movimentação aqui registrada, os agrupamentos, a entrada das crianças menores e animais dentro da escola e a participação de pessoas da comunidade, sem nenhuma restrição, como a educação tradicional do povo Kaingang intui, é que nos fez refletir e levantar questóes. Como será que os estudantes Kaingang que estudam fora da aldeia, acostumados aos seus próprios ritmos, autônomos em suas atitudes, compartilhando o mesmo espaço educacional com seus parentes de diferentes idades, compartilhando materiais escolares, vão se sentir, vão conviver e aprender dentro de uma escola não indígena? E como esse espaço não indígena pode proporcionar relaçóes interculturais? Alguns estudantes da Escola Estadual Indígena de Ensino Fundamental Voga buscam continuar seus estudos fora da aldeia. E quando vão para as escolas não indígenas, quais são suas dificuldades? Como eles se sentem e vivenciam o dia a dia numa instituição escolar distinta da sua?

Os antigos caçadores indígenas estudavam bem os caminhos da mata. Conheciam todos os atalhos que lhes traziam de volta as suas casas e pressentiam os movimentos dos seres da floresta, porque observavam todos esses movimentos, cheiros, ruídos... Caso alguma onça viesse atacá-los sabiam como se defender. Assim são os Kaingang que vivem no meio urbano ou próximo dele. $\mathrm{Na}$ atualidade, precisam conhecer todos os caminhos para que não se percam, buscando ser como aquele antigo caçador que não se perdia na mata, os Kaingang permanecem em sua cultura e procuram manter suas peculiaridades. Porém, será que todos voltam para casa sem identificaçóes com o modo de vida não indígena?

Conviver com os estudantes Kaingang permitiu vê-los como pássaros. E, o professor um estrategista para conquistá-los, para que esses alunos, com asas e vontades próprias fiquem; para que eles não batam suas asas e vão embora. Sentimos que a sala de aula não é uma gaiola de portas fechadas e sim um ambiente que, embora, tenha paredes que enquadrem, que encerrem, o professor mantém a porta aberta, possibilitando uma fluência no ir e vir. As paredes de 
madeiras com frestas deixam entrar o vento e o calor e são testemunhas de um encontro diário de pessoas que dão importância ao compartilhamento dos diversos saberes. Estando a porta aberta, esses pássaros entram, alimentam-se dos sabores e saberes e saem na hora que se sentem saciados. Retornam, não porque se sentem obrigados a frequentar a escola, mas porque sentem vontade de partilhar aquele espaço, de aprender o que está sendo ensinado. O professor é o cuidador desses pássaros. Ele é o responsável pela permanência na escola desses seres com asas, a partir do seu respeito em relaçáo às necessidades e vontades dos alunos-pássaros. Uma perspectiva semelhante foi registrada por Bergamaschi (2005) em suas pesquisas junto às escolas Guarani. Os alunos, independentemente de suas idades, são respeitados em suas vontades e têm autonomia para entrar e sair da escola, sem receber repreensóes por parte dos professores. Nessa pesquisa, a autora relata, por meio do depoimento de professores Guarani, o esforço que precisam fazer para interessar seus alunos, criar um "encantamento" em relação às aprendizagens e assim mantê-los na escola.

Observamos na escola Kaingang que quando o cuidador não está presente na sala, os pássaros são livres e autônomos, decidindo o que querem para si, sem, no entanto, descuidar das atividades escolares que lhes interessa, lhes encanta naquele momento:

Enquanto o professor não chegava, cada aluno que entrava na sala ia escolhendo uma atividade para fazer. Uma menina subiu em uma cadeira e iniciou escrevendo no quadro: "Matemática - História da tartaruga e da perfeiçáo". Copiava de um livro infantil. Uns alunos escolhiam uma atividade em um livro de Geografia, outros desenhavam ou liam. Ao presenciar essa cena, lembrei-me que em uma de minhas observaçóes do ano passado, escrevi que a aula só iniciava quando a sala estava cheia, ou seja, o professor esperava que os alunos fossem se acomodando e ao perceber que a sala estava cheia aí, começava sua aula. E, na medida em que os "atrasados" iam chegando, entravam no ritmo da atividade. Mas hoje, a aula iniciou antes da chegada do professor, provando que a aula realmente começa quando está repleta de alunos. [...] Algumas crianças menores apareceram. Olharam em volta. Saíram. Retornaram. Desenharam e 
brincaram e ao sentirem o cheiro da merenda cessaram o voo. Ficaram para provar desse sabor. (Diário de Campo, 2 jul. 2012).

Nessa escola, vários tipos de pássaros, dos mais cantadores aos visitadores, como o beija-flor, que entra e não para de bater suas asas, abastecendo-se com o cheiro das flores que são os aprendizados, disseminando o pólen que dá origem a outras flores, abastecendo-lhe o corpo e a alma:

Durante essa semana, muitas vezes presenciei o professor passando atividades no quadro enquanto alguns alunos liam um livro, desenhavam, comiam. Crianças menores entravam. Saiam. Olhava em volta para cada aluno e via que muitos estavam fazendo outras atividades, mas no fim da aula quase todos estavam com os cadernos em dia. Uns já tinham resolvido, outros esperavam a hora da correção. Havia uma grande movimentação na sala, pois eles se ajudavam em voz alta, arrastando suas cadeiras e se aproximavam de quem estava conseguindo resolver as atividades do dia. (Diário de Campo, 2 jul. 2012).

Nesse "arrastar das cadeiras”, percebe-se que o corpo das crianças Kaingang não são aprisionados na sala de aula, pois se movimentam, grupam-se de maneira que possam buscar a melhor forma de aprender.

Embora a escola indígena seja considerada muito precária por pessoas não indígenas e até mesmo por alguns indígenas, os estudantes parecem não se importar com a atual realidade, pois não reclamam a todo o momento. Conforme disse o professor, a comunidade quer uma escola nova e já se movimentaram para reivindicar junto às instituições estatais competentes, mas enquanto não a tem, utilizam essa sala de aula sem mostrar insatisfação, sem queixas. Enxergamos em seus olhos atentos e curiosos apenas o entusiasmo de estarem ali.

Numa das entrevistas, o professor mencionou que este prédio escolar a ser construído tem que ter "o rosto do povo Kaingang". Contou-nos que as crianças, antes de terem o mobiliário da sala de aula sentavam no chão e hoje é bem comum sentarem duas crianças na mesma cadeira, compartilhando, amorosamente, o espaço exíguo do mobiliário escolar. Segundo o professor, na filosofia Kaingang não se necessita de um lugar específico para ocorrer o ensino-aprendizagem: 
De baixo de uma árvore também se ensina e se aprende. [...] mas como a escola é uma ferramenta importante para a nossa luta por direitos também queremos uma escola igual a dos brancos, mas com nossa filosofia Kaingang. A escola daqui não vai atender todas as demandas culturais, porque ela não é um instrumento para atender a cultura. A cultura náo cabe para dentro da escola, mas sim só para registro dessa cultura oral. As práticas culturais sáo realizadas num espaço especifico, fora do espaço escolar. A escola indígena prepara os alunos para o outro mundo que está presente. E trabalhar o intelectual não quer dizer que tem que educar as crianças. A educação tem que sair de casa para a sociedade, porque a escola é de todos, mas não é instrumento de educar filhos dos outros. (Entrevista dialogada, 12 set. 2012).

Assim, como não há um lugar específico para ocorrer o ensinoaprendizagem, também não há determinadas imposiçôes, por parte do professor, proibindo-os, por exemplo, de comer enquanto realizam as atividades. Desse modo, a aprendizagem não é condicionada a lugares, regras ou posturas. Por isso, entre os cheiros e os sabores, os alunos Kaingang vão constituindo seus saberes, descobrindo os próprios processos de aprendizagem, observando e, por vezes, imitando as pessoas e os demais seres que participam da vida cotidiana dentro e fora da escola indígena.

Percebemos que a educação faz parte de suas vidas e que ela não é uma função única da escola, pois desde bem pequenas as crianças observam os adultos em seus fazeres e vão os imitando, tentando realizar as atividades. As crianças bem pequenas aprendem observando e repetindo as atividades dos pais, dos irmãos mais velhos, seja na raspagem das taquaras para a confecção do artesanato, ou em outras tarefas diárias. E os adultos os deixam experimentar seus limites, suas potencialidades, porque, desse modo, as crianças sentem-se livres e vão construindo os saberes e se apropriando deles.

A curiosidade é uma aliada nesses experimentos. Bergamaschi (2005), em seu estudo com os Guarani, aponta a curiosidade como uma característica positiva, que vem acompanhada da avidez para aprender a descobrir o mundo por si só. A curiosidade aqui abordada não está solta, está associada à aprendizagem. Tal característica foi observada pela autora ao acompanhar o dia a dia das crianças Guarani, pois intuiu que para compreender a escola, com 
suas significaçóes e possíveis ressignificações precisava primeiro entender como as crianças aprendem no seu próprio modo de vida. Assim, percebeu que a curiosidade de aprender e descobrir o mundo se revela na vontade de aprender. Essa vontade aparece na observação aos fazeres e afazeres das pessoas mais velhas. As crianças observavam também a natureza, sentindo-se fazer parte dela, tendo-a como "fonte de inspiração de vida e de educação" (BERGAMASCHI, 2005, p. 154).

$\mathrm{Na}$ vida cotidiana das crianças Kaingang elas observam suas avós, mães e irmãs durante a confecção dos artesanatos. As crianças sentam ao redor das mulheres, brincam, mas sempre se mostrando atentas e curiosas. Dentro da sala de aula não é diferente, a curiosidade mobiliza o aprendizado e a repetição, como busca da perfeição das tarefas que, constantemente, aparece:

[...] Curiosa, a pequena menina pediu-me para ver a borboleta que desenhei. Tentou desenhar uma. Apagou repetidas vezes, pois desejava ter uma borboleta igual a minha. Elogiei seu desenho, mas ela não se convenceu. Apagou novamente e até que se deu por satisfeita. Sorriu. Assim, contente, pediu lápis de cor para uma colega [...]. (Diário de Campo, 4 jun. 2011).

Destacamos outro exemplo em que a curiosidade e a repetição aparecem com força: uma menina pediu ajuda - isso depois de um tempo de convivência, quando já estávamos numa relação mais íntima e confiante, pois os Kaingang recebem com muita gentileza, contudo estreitam a aproximação quando sentem que é possível uma relação recíproca. As crianças, principalmente, sentem-se à vontade para conversar, para pedir, para oferecer, estabelecendo, assim, uma convivência embasada na reciprocidade.

Enquanto o professor passava no quadro umas contas que para ela já estavam muito fáceis, aproveitou minha disposição. Passei vários exemplos com explicações, ensinando-a como realizar a atividade. Ela se mostrava atenta. Logo começou a desenvolver as contas. Poucas vezes precisou de ajuda. Quando terminou, pediu-me para passar mais. Havia gostado da proposta. Passei vários exercícios, que repetia várias vezes. Essa estudante mostrava muita curiosidade para aprender os conteúdos 
escolares aí dispostos. Como já havia lhe dito que era professora, a aluna queria aprender mais, aproveitando minha proximidade. Me mostrou o seu caderno, pediu que passasse coisas diferentes. Passei-lhe potenciação e raiz quadrada. Senti-me recíproca, íntima, experimentando suas vivências como se, naquele momento, eu fizesse parte daquele mundo. (Diário de Campo, 19 set. 2012).

Esse relato evidencia que além da curiosidade, também entra nesse processo de aprendizagem a repetição. Tanto os alunos como o professor, repetem muitas vezes para ensinar e para aprender. E, embora já dito, achamos importante repetir que a escola indígena ensina prioritariamente conteúdos escolares semelhantes aos da escola não indígena. Porém, o que observamos aqui são modos diferenciados de ensinar e aprender e como já informado por outros estudiosos dos processos de aprendizagem próprios dos povos indígenas, a Escola Voga demonstra em seu cotidiano características dos modos de vida Kaingang.

\section{A Escola Haydée: movimentos para acolher as diferenças}

Enquanto não se ampliam as séries da Escola Voga para o ensino fundamental completo, alguns Kaingang, que saíram da aldeia, estudam nesta escola não indígena. De acordo com os dados informados pelo professor indígena, há aproximadamente 20 estudantes Kaingang que frequentam a Escola Haydée. O professor também pontua que os estudantes da aldeia que continuam seus estudos em escolas não indígenas, sentem a medição, a fragmentação do saber e do conhecimento, pois, segundo ele, há diferenças profundas:

Na nossa escola eu dou a prova para o registro. Um trabalho para complemento. Mas, sei lá, a gente não faz para rodar aluno. A prova e o trabalho servem só para uma avaliação, por questóes burocráticas, porque o conhecimento não tem como ser medido. A gente sabe o aluno que aprova e o que não aprova no dia a dia. [...] A gente tenta separar a Matemática, o Português e o Kaingang, mas assim mesmo uma coisa fica dentro da outra. [...]. (Entrevista dialogada, 12 set. 2012).

Em nossas observaçóes nas duas escolas, no ano de 2011 e 2012, percebemos essa diferença na vivência do tempo, bem como em outros aspectos 
que justificam nossa preocupação com relação aos estudantes indígenas que estudam fora da aldeia. Se na escola indígena há um professor que trabalha todas as disciplinas, além de respeitar as iniciativas dos estudantes, pois cada um tem uma autodeterminação baseada na responsabilidade, na escola não indígena há vários professores e cada um tem uma maneira de organizar o espaço da sala e de trabalhar com os alunos.

[...] Os alunos trabalharam com o livro de Geografia. A atividade era de cópia e resoluçáo de questóes dissertativas. [...] Há uma semelhança na organização do espaço da sala da escola indígena quando a aula é ministrada por esta professora de Geografia, pois ela deixa os alunos ficarem mais à vontade, ou seja, eles sentam em duplas ou trios. Porém, aqui há imposiçóes, restriçóes, regras que são ditas e relembradas várias vezes, durante o período de aula. No terceiro período a professora de Matemática entrou, desfez as duplas, os trios que foram formados na aula de Geografia e organizou a turma em fileiras [...]. (Diário de Campo, 13 abr. 2011).

O professor de Matemática havia trabalhado com a turma disposta em pequenos grupos. Quando chegou outra professora e se deparou com essa disposição ficou muito exaltada. Mostrou-se muito indignada. Exigiu que separassem as classes imediatamente. Os alunos mostraram-se surpresos, mas ao mesmo tempo pareciam estar acostumados com esses "episódios" diários. (Diário de Campo, 12 nov. 2012).

O tempo na Escola Haydée segue o que, historicamente, convencionou-se para as escolas: fragmentado, dividido em períodos. A fragmentação do tempo é um dos principais agentes causadores dos desencontros entre a aula da escola na aldeia e a escola fora dela, que os estudantes Kaingang passam a frequentar para completarem seus estudos no ensino fundamental.

O espaço também é vivenciado de forma muito estática e as experiências que destoam são vistas como "bagunça". Por exemplo, a professora de Matemática encaminhou um trabalho que, em seu desenvolvimento, parecia estar sendo bem produtivo, isso evidenciado pelo envolvimento dos alunos na realização da atividade. Mesmo permeada por risos e conversas, eles estavam 
resolvendo as questóes propostas pela professora, que os orientava quando necessário. $\mathrm{Na}$ troca de período, não teve como reorganizar a sala antes da próxima colega assumir a turma. Essa nova professora que chegou, diante da suposta desordem da sala de aula naquele instante, não enxergou a possibilidade de fazer o seu trabalho com os alunos dispostos em grupos. Não percebeu essa desordem momentânea como possibilidades para uma ordem posterior, em que se agregariam potências para as aprendizagens. É evidente que a escola se apresenta como um turbilhão, no dizer de Bedin (2006). O autor, ao realizar sua pesquisa com uma escola pública, comparou-a a um turbilhão, pois todos os dias aconteciam surpresas. Essa turbulência de balburdio, brigas, barulhos de classes e cadeiras sendo arrastadas e gritarias, preenchia o espaço da escola, contagiando os sujeitos que nela conviviam. $\mathrm{O}$ turbilhão que nos referimos aqui são essas surpresas cotidianas, que penetram no corpo e na mente, muitas vezes produzindo impotência e desconforto, mas que podem conter possibilidades de criação.

Nessa perspectiva, torna-se possível pensar na contribuição da sabedoria indígena quanto ao gerenciamento do tempo e do espaço, ou com a pouca importância que mostram ter para as prescriçóes do papel, que servem apenas como um mero registro e não (com)provam de fato o que o aluno sabe ou não. Nesse contexto, podemos pensar em como está ocorrendo a aprendizagem dos estudantes Kaingang - bem como dos demais estudantes, pois a Escola Haydée está organizada de acordo com as concepçóes ocidentais de tempo e espaço, distribuindo as crianças de idades diferentes em salas separadas, organizando seu espaço com classes individuais, separando as disciplinas e em conformidade com horário e regras rígidas. Por outro lado, a escola indígena é multisseriada, onde crianças convivem com diferentes idades e diferentes níveis de conhecimento, que se movimentam conforme as suas vontades e o tempo de cada uma é respeitado na realização das atividades. Regras também existem nessa escola, porém, lá há uma diferença: elas não precisam ser ditas e (re)lembradas o tempo inteiro. Assim, a aula flui e cada estudante parece saber como agir - ou é respeitado em seu processo -, mostrando autonomia e responsabilidade nas suas escolhas.

Na escola Haydée, que está organizada como a grande maioria das, os estudantes Kaingang tentam viver dentro desse tempo, mas encontram muitas dificuldades. Além de situaçóes de sala de aula em que, na realização das atividades são apressados pelos professores com incentivos para "concluir”, para 
"fazer mais rápido", devido à pressão que também sofrem com o enquadramento do tempo, surge o problema das "faltas", ou seja, as ausências registradas no caderno de chamada, principalmente das meninas Kaingang. Esses estudantes Kaingang, em uma conversa coletiva, disseram que várias vezes chegaram à escola e depararam-se com os portóes fechados, pois não se dispunham ao tempo proposto pela instituição. Às vezes, voltavam para a casa ou ficavam na frente da escola com outros colegas, o que gerava comentários depreciativos como se eles tivessem "matando aula".

Percebe-se que há pontos discrepantes entre as duas escolas, mas também podemos encontrar semelhanças. Uma delas é o fato das escolas serem frequentadas por vários grupos humanos e cada um com o seu conjunto de características, como a sua vida social. E, nesse conviver, a interculturalidade aparece com força. Nosso entendimento de interculturalidade aproxima-se das ideias de Canclini (2007), que diz da relação de duas ou mais culturas que se entrelaçam, como os fios de um cesto de diversas cores que vemos ser confeccionados pelas mulheres Kaingang na aldeia Por Fi. Os fios são simbolizados pelas culturas de cada povo e as cores são símbolos das apropriaçóes, dos novos significados de cada cultura que se apropria e ressignifica, podendo ser objetos materiais, como roupas, alimentos, celulares, bem como uma gama de conhecimentos e saberes.

Portanto, compreendemos que a interculturalidade acontece quando há esse entrelaçamento, pois é através das diferenças que se constrói algo novo. Salientamos que, de acordo com Canclini (2007), não excluímos as negociaçóes e os conflitos que, necessariamente, estão presentes nas relaçôes interculturais.

\section{As cores da convivência}

Se a imagem usada para dizer da escola indígena foi o cesto, peça característica da arte Kaingang que diariamente está em construçáo e representa o movimento, o trançado colorido dos fazeres Kaingang, na Escola Haydée a imagem também pode ser de um cesto, só que este já está construído, já está pronto. Aqui, as fibras já estão trançadas, sem que lembre explicitamente dos movimentos que o teceram; suas cores estão desbotadas. Porém, este cesto, talvez, possa ser (des)construído e trançado agora, também com a participação das pessoas Kaingang que trazem um outro olhar sobre a educação. Segundo Melià (1979), a educação indígena pode apontar soluçôes para a educação 
não indígena, principalmente porque muitas de nossas crenças educacionais precisam ser reelaboradas, reescritas. Quem sabe os Kaingang poderão contribuir nesse (re)fazer, nessa (re)construção da educação escolarizada?

Sabemos que são poucos estudantes Kaingang na Escola Haydée e, em geral, passam despercebidos. Igualmente, sabemos que em meio ao ritmo diário das pessoas que fazem a escola e absorvidos pelas necessidades imediatas, o exercício da reflexão, basicamente, não consegue se assentarem nessa pressa, na explícita fadiga física e psicológica de professores, gestores, funcionários, pais, mães, estudantes. Concordamos com Bedin (2006), para pensar a escola e todos os seus problemas há a necessidade de se distanciar dela, é preciso ter tranquilidade para perceber suas práticas pedagógicas.

Muros altos em torno da escola encobrem as cores entre canteiros de diversas flores e árvores plantadas e planejadas por pessoas que sonharam essa escola: "Quando eu cheguei aqui, há vinte anos, essa escola era feia. Não dava vontade de trabalhar nessa escola. Ai a gente plantou essas árvores... Agora ela está linda!' (Depoimento de uma das professoras da Escola Haydée, 20 nov. 2012). A construção dos muros, pensada como estratégia para proteção para as pessoas que aí estudam e trabalham, não impede de escutarmos a alegria dos alunos que gritam e correm por todos os lados na hora dos intervalos. Ultrapassando os muros da escola encontramos pessoas que experienciam (in)tensamente suas vicissitudes. Percebemos as marcas de pessoas que permanecem nessa escola, seja pela coragem e ousadia ou pelo conformismo. Percebemos também um forte envolvimento com as questôes da educação a partir das expressóes dos modos de ser e estar na escola, seja pelas demonstraçóes de alegria, de (in)conformismo, de raiva, de (in)compreensóes ou preconceito:

Sem eu perguntar nada, a professora sentou-se ao meu lado e começou a dizer como cada estudante Kaingang era (aos olhos dela): "Curruíra ${ }^{2}$ é enturmado até demais, Beija-Flor gosta de aparecer, Sabiá é revoltado quando alguém fala dos índios, ele vive no mundo da lua. Eu, às vezes, fico louca com esses indiozinhos que esquecem o livro, que não fazem os temas [...]. (Diário de Campo, 1 out. 2013).

O trecho acima mostra a sensibilidade de uma pessoa envolvida e mergulhada nesse universo escolar. Conquanto as invisibilidades e discriminaçóes vivenciadas pelos estudantes indígenas, que sofrem desde a indiferença até a 
culpabilização por não aprenderem da forma imaginada por alguns professores, pequenos movimentos mostram como as pessoas dessa comunidade estáo experimentando a convivência com os estudantes Kaingang. Mesmo diante de falas expressivas que deixavam escapar as estratégias da homogeneização frente à diversidade, principalmente tratando-se da turma com maior número de estudantes indígenas, turma esta considerada pela escola como a que apresenta as maiores dificuldades, observamos atitudes generosas, na disposição de explicar quantas vezes fossem necessárias e a afetividade em seu tom de voz, quando alguém lhe pedia mais uma folha, ou uma régua emprestada.

Observamos outra atitude respeitosa: um professor que parecia tratar os estudantes Kaingang como tratava os outros alunos, explicava-lhes da mesma forma, dispunha-se da mesma maneira. Não tinha nenhum conhecimento sobre a cultura indígena, como ele mesmo revelou na entrevista, mas isso não o impediu de cumprir um papel importante do professor, de também ser um orientador. A diferença cultural e as outras diferenças que toda a comunidade enxerga e se queixa náo foram obstáculos para o professor desempenhar seu trabalho.

Hoje assisti dois períodos de aula dados por Cravo. O professor havia levado um rádio, pois me pareceu, a partir de seu diálogo, que era uma combinação estabelecida em comum acordo, entre ele e a turma. Mas, a cena mais interessante da tarde foi o modo como o professor explicou para um estudante Kaingang como resolver uma expressão fracionária. Não gravei. Não anotei nada, observei. Através de suas palavras, de suas perguntas e principalmente das respostas do garoto, o professor ia abrindo espaço para que esse estudante pudesse compreender como realizar a atividade. Porém, o que marcou mais foi a valorização, por parte do professor, daquilo que o estudante já conhecia, pois naquele momento parecia que para aquele professor, a realização correta da atividade era menos importante. Estava se estabelecendo ali uma compreensão por parte do professor de que o estudante Kaingang não tinha limitaçóes intelectuais, apenas não teve acesso àquele conhecimento. (Diário de Campo, 8 nov. 2012). 
A postura desse professor nos convida à construção de redes interculturais. A disposiçáo em vivenciar o cotidiano dessa turma possibilitou sentir que a sensibilização da comunidade escolar Haydée seria um espaço para a germinação da interculturalidade. A escola é um espaço intercultural quando há possibilidades de trocas, quando não há resistência às mudanças, quando se revitaliza a forma de transmitir e construir conhecimentos, permitindo que novos conhecimentos façam parte das ciências da escola. Sentimos que, adentrando os muros da escola, também podemos encontrar sujeitos envolvidos e comprometidos com a educação e dispostos a não mais seguir o modelo educacional que parece não funcionar como fora planejado, e que, talvez, nunca tenha funcionado de verdade.

Porém, a mais bela surpresa da pesquisa foi em relação aos alunos, evidenciando companheirismo e cumplicidade. Eles aprendem uns com os outros sem perceberem que estão aprendendo. Esse aprender está relacionado a não recusa à diferença e permeia as atividades do dia a dia, como mostra o excerto do Diário de Campo (11 out. 2012):

No recreio os meninos se abraçam, correm atrás da bola, suam e gritam inúmeras vezes. Os meninos Kaingang estão jogando. Sáo disputados pelos colegas. Sentada no banco perto do campo sinto uma forte energia vinda daqueles corpos que se movimentam como se estivessem dançando. Gol! Um estudante Kaingang fez um gol! Um belo gol! É hora da comemoraçáo e vem mais abraços e gritos. O sinal de entrada já bateu e a bola continua rolando e de pé em pé vai se movimentando. A professora entra na sala e os meninos continuam jogando. Antes de entrarem, um dos estudantes ensina como fazer malabarismo com a bola que escorrega pelo pescoço até as costas, volta e desliza pelos braços e cai direto no pé. Foi uma farra! Ninguém queria entrar na aula, porque queriam aprender aquele espetáculo!

Entre os estudantes indígenas e não indígenas transparece afinidades, brigas, brincadeiras, convites, algazarras, conflitos, mas, sobretudo, a cumplicidade: cúmplices na vivência de um cotidiano escolar carregado de emoções, de desafios, de conflitos entre professores e alunos; entre alunos e alunos. Evidenciava-se a cumplicidade quando algum estudante era xingado 
por um(a) professor(a), por exemplo, pois havia sempre alguém para defender o colega que estava sendo chamado atenção em demasia frente à turma. $\mathrm{Ou}$, quando queriam sair mais cedo para o recreio, argumentavam, solicitavam, todos juntos, unidos para que conseguissem alcançar o alvo desejado.

Possivelmente, tais cenas são visualizadas em outros contextos escolares, mas o que buscamos aqui é ressaltar a positividade da uniáo, da parceria, muitas vezes enxergada como um obstáculo para se realizar o trabalho docente em sala de aula. A partir dessa relação emergem potencialidades; a união parece mostrar a aceitação das diferenças que havia na turma, não só dos estudantes Kaingang, considerados mais vulneráveis aos conflitos produzidos a partir das diversidades.

Observamos, no dia a dia, que esses estudantes também tiram proveito positivo das diferenças, como, por exemplo, para a realização de atividades grupais. Nas propostas de atividades em grupos sempre tem alguém com mais facilidade de realizar as tarefas, são mais hábeis para construir algo criativo. Uns apresentam habilidade de desenhar, resolver problemas, escrever, criar poesias e, assim, os grupos vão se formando, não só a partir das afinidades, mas, também, a partir das diferenças:

No primeiro dia que observei a aula de Ensino Religioso, a professora propôs um trabalho em grupo: "Criar uma música com tema livre". Ela solicitou que formassem 3 grupos de 7 pessoas. Fizeram 4 grupos, pois por afinidade uns estudantes não indígenas queriam fazer parte do grupo dos colegas Kaingang. Formaram-se então grupos com números diferentes. Depois fui descobrir que os estudantes Kaingang gostavam muito de cantar e criar letras de música, por isso que uns colegas "aproveitaram" para pedir para trocar de grupo e fazer parte do grupo dos “colegas da aldeia”. (Diário de Campo, 17 out. 2012).

O termo "colegas da aldeia" foi expresso por uma professora. Pareceu-nos uma expressão sem pretensão pejorativa, pois ela tinha certa "intimidade" com os estudantes Kaingang. A professora brincava muito com todos os estudantes e os Kaingang mostraram-se abertos às brincadeiras. Eles mesmos brincavam com o nome de seu povo fazendo analogia como "nós somos os índios da gang". Muitos professores achavam que esses estudantes estavam ridicularizando sua cultura, mas parecia que por trás dessa brincadeira havia outra lógica. A lógica 
de que eles, simplesmente, estavam mostrando sua criatividade e que de certa forma, eles pertenciam sim a outra "gang", como se "gang" tivesse o sentido de "tribo", de etnia.

Essas e outras situaçôes mostram estudantes Kaingang "enturmados" com os demais colegas. Não foram observadas atitudes de discriminaçấo por parte dos colegas não indígenas:

Os Kaingang se relacionam bem com os colegas, pois parece-me que para os demais estudantes não indígenas não há diferença entre eles. [...] As meninas Kaingang que, parecem ser mais reservadas, estão sempre juntas e não observei situaçóes de discriminação. Há um menino que está sempre conversando com elas e faz trabalhos em dupla com uma das estudantes Kaingang. Já os meninos Kaingang estão sempre brincando, rindo muito. Eles mesmos fazem brincadeiras com a sua etnia, mexem com os outros e quando não entendem alguma brincadeira por parte dos colegas, ficam quietos, ou riem junto, sem saber por que. (Diário de Campo, 11 out. 2012).

Talvez, as brincadeiras que fazem seja uma forma de lidar com os possíveis conflitos. Contudo, observando as vivências diárias em uma turma de $6^{\circ}$ ano, percebe-se que os estudantes Kaingang acharam uma estratégia de conviver na escola não indígena. Eles se enturmaram e, mesmo algumas vezes sofrendo preconceitos, mostram-se inseridos num grupo. Embora com a convivência haja maior entrosamento entre os colegas, aparecem desentendimentos e maiores incompreensóes com os professores. Parece que há uma lacuna entre eles e essa "separação" pode ser percebida nos depoimentos de alguns docentes, ao falarem sobre a cultura Kaingang, por exemplo: "os indígenas não falam sobre sua própria cultura, não a mostram nas danças, no dia do indio [...] não valorizam sua cultura [...] cantam as músicas da nossa sociedade e não cantam as deles". São declaraçôes que evidenciam entendimentos parciais de cultura, como se ela se restringisse às danças, aos jogos, ou seja, ao exótico, não havendo a compreensão de que tal conceito diz respeito aos modos de vida, à própria construção de conhecimentos. Todorov (2010) nos diz que cultura é como vivemos, nosso modo de pensar, de se vestir, nossa língua e religião e outros modos de ser. Situaçôes registradas no cotidiano escolar faz parecer que algumas pessoas imaginam que os estudantes Kaingang, para parecerem indígenas, tivessem que frequentar a escola com 
penachos na cabeça, usando tangas, arcos e flechas, pois acreditam que esses sejam os traços da cultura que devam aparecer.

A partir dessa incompreensão e percebendo outros desencontros, é possível pensar porque os estudantes Kaingang não falam sobre sua cultura, como é sua vida na aldeia Por Fi. Se os estudantes Kaingang não falam sobre sua cultura é por que ela é sentida, vivida no dia a dia em sua comunidade, pois ali, na escola ocidental, eles estão vendo, ouvindo e sentindo outras concepçóes culturais. E é dentro desse ambiente escolar não indígena que os Kaingang experimentam uma convivência intercultural: quando eles cantam, quando se identificam com os colegas tanto no estilo musical como nas roupas que vestem, quando se apropriam dos objetos e roupas e dáo novos significados e quando querem estar-junto desse outro para dele abstrair o que lhes servirá para suas vidas.

\section{Algumas palavras para concluir}

Mergulhando na questáo principal desse estudo e relacionando-a com a aceitação das diferenças que aparecem entre os estudantes, podemos concluir que eles estão mais propícios a uma relação intercultural respeitosa do que os próprios professores, a equipe diretiva e as demais pessoas que fazem parte da comunidade Haydée. Isso talvez ocorra, porque, de acordo com Fleuri e Souza (2003, p. 82):

Provavelmente, um dos fatores que obstruem a passagem para a relação entre culturas, no espaço educacional, é a cultura escolar formal e normatizadora, a nossa concepção de cultura como transmissão e assimilação de conhecimentos, que manda para os lados externos da escola a relação entre aprendizagem e elaboração, tão presente nas brincadeiras ente as crianças.

Observamos também que os estudantes Kaingang aproveitam a convivência com a comunidade não indígena para conhecer a cultura ocidental. Essa é uma das possibilidades para a interculturalidade, que pressupóe a reciprocidade como equidade de saberes, nessa situação evidenciada pela vontade de interagir, de conhecer o outro e de trocar. A partir da vontade de (re) conhecer o outro, da cumplicidade entre os estudantes, da união, da aceitação das diferenças, aflora a potência do encontro intercultural. Esse ensejo está no 
inter da relação, mobiliza a interculturalidade e, por meio de diálogos, os espaços interculturais podem se estender. Nesse sentido, acreditamos que, a partir da efetivação de diálogos entre a comunidade Haydée e a comunidade Kaingang, abrem-se espaços para que as experiências interculturais sejam vivenciadas não só pelos estudantes Kaingang, mas também pelas demais pessoas não indígenas que convivem com eles, diariamente.

Ficou evidente para nós que a convivência entre os estudantes indígenas e não indígenas mostram caminhos para a interculturalidade a partir não só dos conflitos, mas também das trocas, da cumplicidade e da aceitação das diferenças, embora, entre os professores e as demais pessoas náo indígenas da comunidade Haydée, predomine, até o momento, o campo dos conflitos. Em meio ao emaranhado de incompreensôes, preconceitos e turbulências vividos no cotidiano escolar, vislumbramos também possibilidades, assim como Bedin (2006), de que os sujeitos das comunidades escolares pesquisadas enxerguem as suas próprias potências, que descubram caminhos interculturais, pois mesmo havendo um pequeno grupo de estudantes Kaingang saindo de suas aldeias e frequentando a instituição escolar não indígena, o que observamos nessa escola nos mostra que a desacomodaçáo começa a acontecer, abrindo sendas para aprendizagens recíprocas.

\section{Notas}

${ }^{1} \mathrm{O}$ estar-junto constitui uma forma privilegiada de com-vivência, de vivência com-junta. Esse "estar-junto", que escolhemos como a base do trabalho de campo na elaboração da etnografia, busca uma "justa visão daquilo que é o outro", um "identificar-se com ele, ainda que seja de modo provisório, e examinar seus atos a partir do interior, sem a prioris judicativos ou normativos" (MAFFESOLI, 2001, p. 142).

${ }^{2}$ A fim de evitar identificaçóes, na pesquisa todos os estudantes que dela participaram são identificados com nomes de pássaros e os professores da escola não indígena com nomes de flores.

\section{REFERÊNCIAS}

BEDIN, Silvio Antônio. Escola: da magia da criação - as éticas que sustentam a escola pública. Passo Fundo, RS: Editora da UPF, 2006. 
BERGAMASCHI, Maria Aparecida. Nembo'e: Enquanto o encanto permanece! Processos e práticas de escolarização nas aldeias Guarani. 2005. Tese (Doutorado em Educação) - Universidade Federal do Rio Grande do Sul, Porto Alegre, 2005.

CANCLINI, Néstor Garcia. Diferentes, desiguais e desconectados - mapas da interculturalidade. Rio de Janeiro: Editora da UFRJ, 2007.

CARDOSO, Dorvalino Refej. Aprendendo com todas as formas de vida do planeta: educação oral e educação escolar Kanhgág. 2014. Monografia (Licenciatura em Pedagogia) - Universidade Federal do Rio Grande do Sul, Porto Alegre, 2014.

CLAUDINO, Zaqueu Key. Educação Indigena em diálogo. Pelotas, RS: Editora da UFPel, 2009.

FLEURI, Reinaldo Matias; SOUZA, Maria Izabel Porto. Entre limites e limiares de culturas: educação na perspectiva intercultural. In: FLEURI, Reinaldo Matias (Org.). Educação Intercultural: mediações necessárias. Rio de Janeiro: DP\&A, 2003.

FREITAS, de Castro Ana Elisa. Territórios ameríndios: espaços de vida nativa no Brasil meridional. In: BERGAMASCHI, Maria Aparecida (Org.). Povos Indígenas \& Educação. Porto Alegre: Mediação, 2008. p. 17-28.

LIMA, Antônio Carlos de. Um grande cerco de paz: poder tutelar, indianidade e formação do Estado no Brasil. Petrópolis, RJ: Vozes, 1995.

MAFFESOLI, Michel. No fundo das aparências. Petrópolis, RJ: Vozes, 1999.

MAFFESOLI, Michel. Elogio da razão sensivel. 2. ed. Petrópolis, RJ: Vozes, 2001.

MELIÀ, Bartomeu. Educação Indígena e alfabetização. São Paulo: Loyola, 1979.

SILVA, Sergio Baptista. Contato interétnico e dinâmica sociocultural: os casos Guarani e Kaingang no Rio Grande do Sul. In: BERGAMASCHI, Maria Aparecida (Org.). Povos Indígenas \& Educação. Porto Alegre: Mediação, 2008. p. 29-43.

TODOROV, Tzvetan. O medo dos bárbaros: para além do choque das civilizações. Petrópolis, RJ: Vozes, 2010. 


\section{Estudiantes indígenas en una escuela no indígena: posibilidades para vivencias interculturales}

\section{Resumen}

El estudio que presentamos resulta de la investigación en una escuela indígena y en una escuela no indígena, realizada básicamente en la perspectiva metodológica etnográfica durante los años 2011 y 2012. En esta última escuela fue observada la convivencia con estudiantes Kaingang que concluyen la educación fundamental, iniciada en la escuela de la aldea. A partir de este estudio etnográfico, describimos situaciones que muestran a la educación y a la escuela en el cotidiano Kaingang, así como el cotidiano de la escuela no indígena, como ocurre la convivencia y las posibilidades para la interculturalidad, las conflictualidades y las relaciones de reciprocidad. La mirada que dedicamos para conocer y describir esta relación abre un campo de posibilidades resultantes de intercambios - a veces desconfianzas y aislamientos que ofrecen contribuciones importantes, tanto para la educación y la escuela indígena como para la educación y la escuela no indígena.

Palabras claves: Interculturalidad. Educación Indígena. Educación y Escuela Kaingang.
Indigenous students in a nonindigenous school: a chance for intercultural experiences Abstract

The study we present stems from a research made at an indigenous school and at a non-indigenous school. The research was basically made under the ethnographic methodology, during the years of 2011 and 2012. At the latter school, we observed the interaction with the Kaingang students that are graduating at elementary school, which they had first started at their village school. Having that ethnography as a starting point, we describe scenarios that represent education and school on the Kaingang everyday life, as well as the common day of the non-indigenous school, and how the interactions occur and what are the possibilities for intercultural and conflicting meetings and the reciprocity relations. The attentive eyes we lay upon this research in order to get to know and to describe this relation opens a world of possibilities that result from exchange situations in which sometimes there is distrust or isolation - and they offer important contribution both to the indigenous school and education and to the nonindigenous school and education.

Keywords: Intercultural. Indigenous Education. Kaingang School and Education. 
Maria Aparecida Bergamaschi

E-mail: cida.bergamaschi@gmail.com

Kátia Simone Müller Dickel

E-mail: katiamuller.dickel13@gmail.com

Enviado em: 13/8/2014 Aprovado em: 29/11/2014 